\title{
Precision engineering for optical applications: knowledge transfer into UK industry
}

Christopher Sansom, Paul Shore

Christopher Sansom, Paul Shore, "Precision engineering for optical applications: knowledge transfer into UK industry," Proc. SPIE 9666, 11th Education and Training in Optics and Photonics Conference, $96660 Z$ ( 5 June 2009); doi: 10.1117/12.2208031

EDIE Event: Eleventh International Topical Meeting on Education and Training in Optics and Photonics, 2009, St. Asaph, United Kingdom 


\title{
Precision engineering for optical applications: Knowledge Transfer into UK industry
}

\author{
Christopher Sansom and Paul Shore \\ Precision Engineering Centre, Cranfield University, Cranfield MK43 OAL, UK
}

ABSTRACT

A means of facilitating the transfer of precision engineering knowledge and skills from academic institutions and their research partners into UK optics and optical engineering companies is described. The process involves the creation of an Integrated Knowledge Centre (IKC), a partnership led by Cranfield University with the support of the University of Cambridge, University College London, and the OpTIC technium. This paper describes the development of the three main vehicles for knowledge transfer. These are a Masters level postgraduate degree course (the Cranfield University led MSc in "Ultra Precision Technologies"), a portfolio of industrial short courses which are designed to address key skills shortages in the fields of precision engineering for optical applications, and an e-learning package in precision engineering. The main issues encountered during the development of the knowledge transfer teaching and learning packages are discussed, and the outcomes from the first year of knowledge transfer activities are described. In overall summary, the results demonstrate how the Integrated Knowledge Centre in Ultra Precision and Structured Surfaces' approach to knowledge transfer has been effective in addressing the engineering skills gap in precision optics based industries.

\section{Keywords}

Knowledge Transfer, Precision Engineering, Ultra Precision Optics, Postgraduate Masters degree.

\section{INTRODUCTION}

A number of UK manufacturing sectors require staff with postgraduate level skills in ultra precision technologies and applications. These sectors include, optics and optoelectronics, space, energy generation (including nuclear fusion and solar), and display technology. The common thread running through all of these products and applications is the need for skilled mechanical engineers with an additional specialization in the field of ultra precision. Within the UK, the large optics and optical components sectors are of strategic importance. As a result, a shortage of engineers with the skills to precisely machine materials for optics and optically-based products needs to be addressed as a matter of some urgency.

\section{UK INDUSTRIAL CONTEXT}

The UK ultra precision optics industries are thriving, despite challenging economic environments and the increasingly competitive globalisation of its markets. However the demand for the specialist mechanical engineering skills needed to realise the opportunities presented by the expansion of the technologically advanced customers within the new economies has not been matched by the supply.

The need for greater integration between UK Higher Education and the manufacturing sector has been well documented ${ }^{1}$. From the industrialist's standpoint there are a bewildering number of undergraduate and postgraduate courses that feed into the labour market. Similarly there are a large number of Higher Education establishments that provide training, often with very different learning objectives for their students. Without any guidance it is often difficult for a manufacturing organization to recruit effectively in this environment. The recruitment operation is seen as a one-way process with little or no opportunity for the specialized needs of the manufacturer to be catered for. The student, employer, and the academic institution are essentially remote and isolated from each other. In such circumstances the successful recruitment of employable and technically capable staff becomes largely a matter of chance. 
This is particularly true for the recruitment of ultra precision engineers into the precision optics sector of UK business. Here a prospective employer must decide whether to recruit a seasoned professional, or a new/recent graduate. The individual will probably possess a first or second degree from one of 117 academic institutions of Higher Education within the UK, in a subject including mechanical engineering, physics, material science, electronic engineering, general engineering, and chemistry. It is against this backdrop that the Integrated Knowledge Centre (IKC) in Ultra Precision Structured Surfaces (UPS ${ }^{2}$ ) and the Cranfield University led Knowledge Transfer activities were conceived, as discussed in the next section.

\section{THE INTEGRATED KNOWLEDGE CENTRE (IKC) IN PRECISION ENGINEERING}

Partnerships between academic institutions and manufacturing industry have been developed in a number of fields, including mechanical engineering ${ }^{2}$. In the current context of UK ultra precision engineering for optical applications this link is provided by a unique partnership between UK academia and industry, the UPS ${ }^{2}$ Integrated Knowledge Centre (IKC), located at the Technium OpTIC within the North Wales optics and optoelectronics business cluster. (see Figure 1).

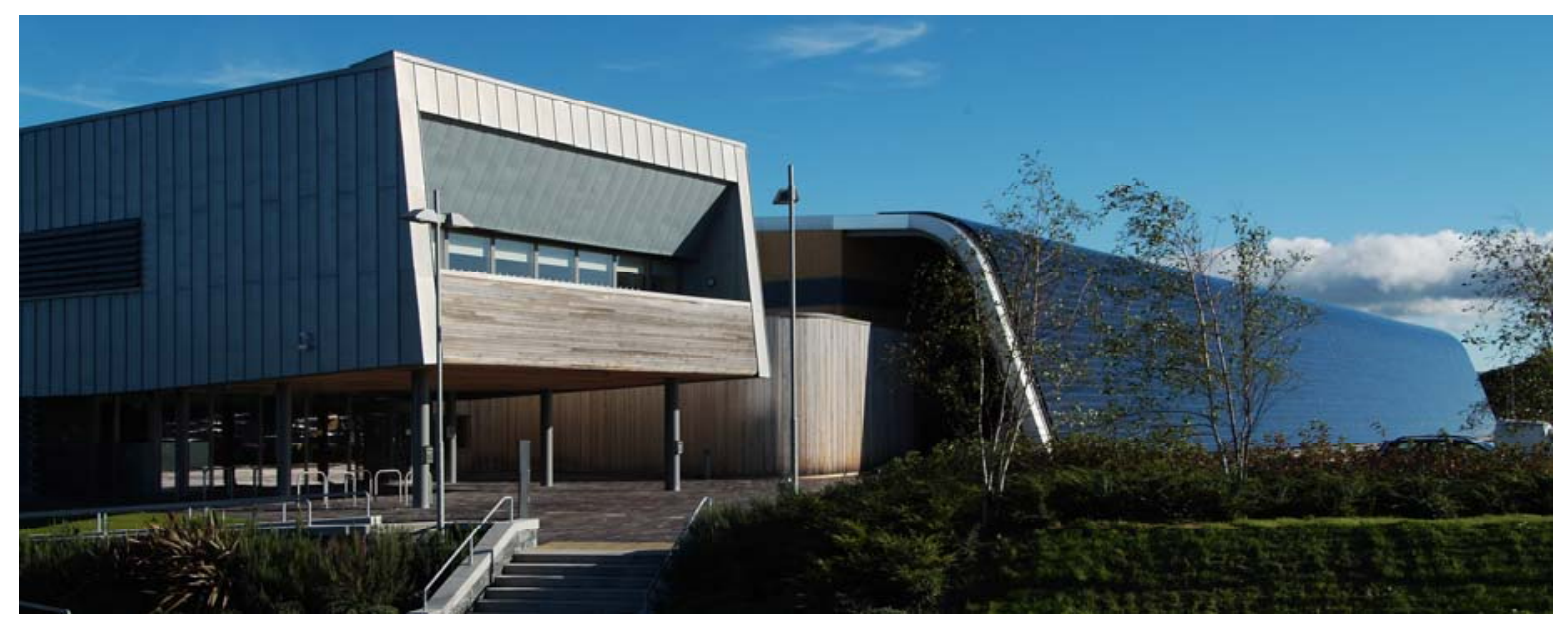

Figure 1. Technium OpTIC, base of the IKC in Ultra Precision and Structured Surfaces (UPS ${ }^{2}$ )

The Ultra Precision and Structured Surfaces Integrated Knowledge Centre (UPS ${ }^{2}$ ) is the cornerstone of an EPSRC funded approach to support UK industry through a range of industry-facing technology transfer initiatives. Its success is to be identified as a self-funding UK Centre of Excellence housed at the Technium OpTIC. It is working towards world class research facilities with a vibrant research and IP portfolio, supporting participating companies. Although it is the knowledge transfer activities that are of most interest in the context of this paper, there is an opportunity for optical engineering and photonics partners to link through facilities, equipment, plus research and development.

\section{SYSTEMIC LINKAGE BETWEEN INDUSTRY AND ACADEMIA}

The MSc in "Ultra Precision Technologies" is the flagship of the IKC knowledge transfer programme, and reflects the strength of the link between academia and the needs of precision engineering businesses. This link is illustrated schematically ${ }^{3}$ in Figure 2 . In the model the students are regarded as inputs to a teaching and learning system, with corresponding outputs. However there is a need for stronger links between students, academia and industry throughout the whole sequence of processes that make up the system. This has been addressed by the addition of an intermediate shell of sub-systems which are described in Figure 2 in systems terms as the "Course-level interface" and "Company, Student, and HE establishment engagement" subsystems; and define the role of a dedicated HE academic or professional. It is through this structure that the 
precision engineering and optical application industries are able to play a proactive part in all of the key activities from student recruitment to course design.

The roles played by the industrial partners and the proactive links between the University and its engineering sponsors are described in the context of the Cranfield University led MSc in "Ultra Precision Technologies" in the following section.

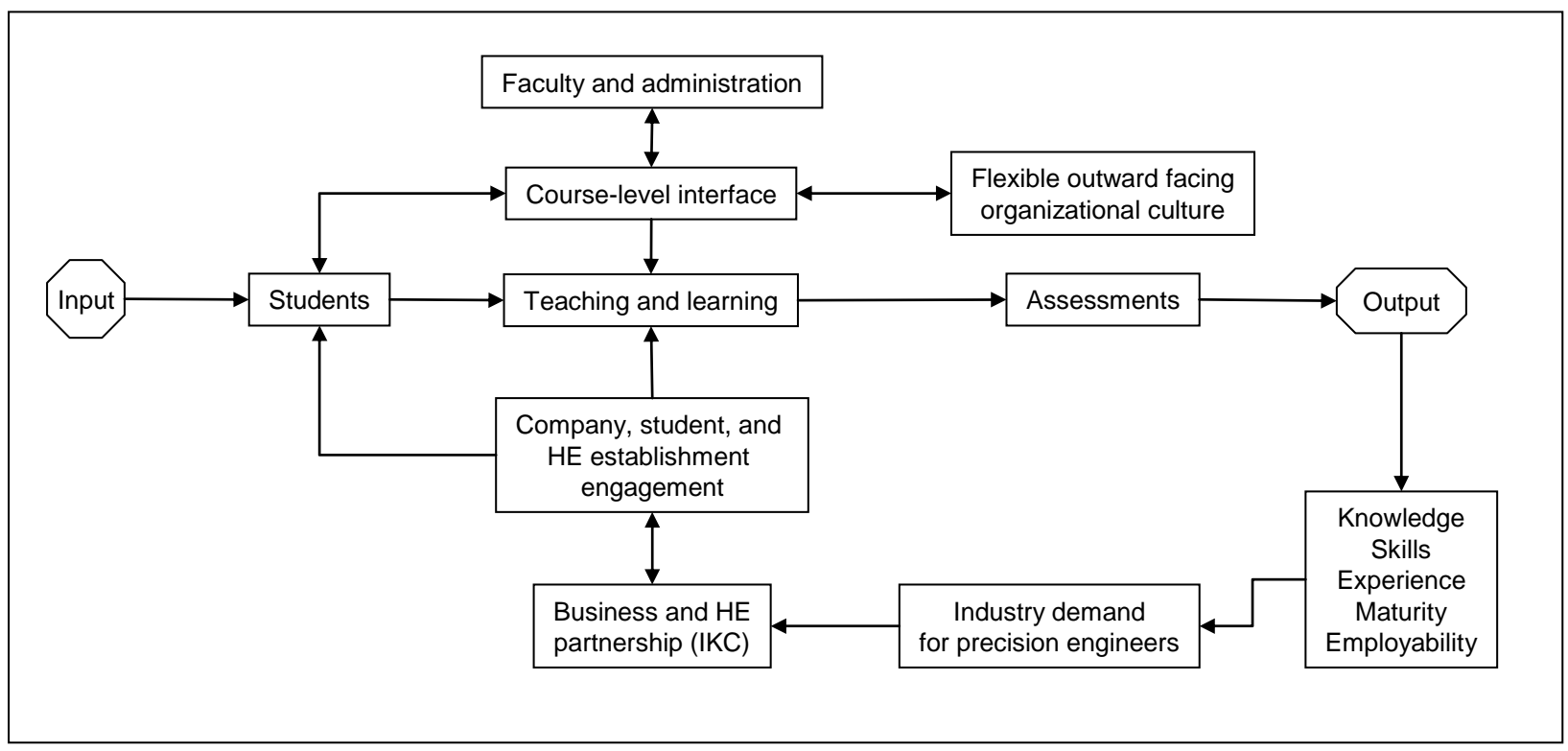

Figure 2 - Academic - Industry links for the MSc in Ultra Precision Technologies ${ }^{3}$

\section{TEACHING AND LEARNING - MSc IN ULTRA PRECISION TECHNOLOGIES}

The concept of the course, and its role in attempting to address a UK skill shortage for precision engineers, is a direct response to the needs of the UK "large optics" industrialists - expressed through the appropriate research councils. Simply, there is an urgent need for skilled and employable precision and ultra-precision engineers who can employ those skills effectively in an optics and photonics industrial environment. In order to meet these criteria a one-year full-time Masters degree course was constructed. The Masters (M-level) structure has the benefit of joining three components of study within a proven overall framework. These are a block of taught courses or modules), a group project, and an individual project which is written up as a thesis.

\subsection{Taught elements}

The taught modules are listed in Table 1 . The topics reflect the engineering skills required to be learned, the applications to be addressed, and the business skills that will aid new products and wealth generation. The "Precision Engineering" module contains the core of the precision engineering principles and techniques for optical applications - such as grinding, polishing, and plasma technology for advanced 3D form, figuring and roughness adjustment. The "Metrology and Optical Test" module explains how the drive for ultra-precision drives the push for ultra-precise measurement. Since the required accuracies are fractions of a wavelength, optical techniques predominate. In line with the prerequisite for excellence in both teaching and learning the course includes an in-depth series of lectures in Interferometry from Professor Jim Wyant of the University of Arizona. Module 3, entitled "Managing Innovation and New Product Development", is unique in its brief to develop the student's managerial skills. This is in response to an industrial need for engineering students who have a good appreciation of entrepreneurship and the creation of new products within a manufacturing environment. In a wider industrial context it also prepares the student for the role of a new business creator. 


\begin{tabular}{|c|c|c|c|}
\hline Subject & Co-ordinators & External Partners & Location / date \\
\hline Precision Engineering & $\begin{array}{l}\text { Cranfield, Precision } \\
\text { Engineering Centre }\end{array}$ & University of Huddersfield, MIT, Euspen & Cranfield, Oct. \\
\hline $\begin{array}{l}\text { Metrology and Optical } \\
\text { Testing }\end{array}$ & $\begin{array}{l}\text { Cranfield, Precision } \\
\text { Engineering Centre and } \\
\text { OpTIC }\end{array}$ & $\begin{array}{l}\text { University of Huddersfield, } \\
\text { University of Arizona, } \\
\text { ETH Zurich, } \\
\text { Philips Applied Technologies }\end{array}$ & OpTIC, Oct \\
\hline $\begin{array}{l}\text { Managing Innovation and } \\
\text { New Product Development }\end{array}$ & $\begin{array}{l}\text { Cranfield, School of } \\
\text { Management }\end{array}$ & Institute for Manufacturing, Cambridge & Cranfield, Nov \\
\hline $\begin{array}{l}\text { Computer-aided engineering } \\
\text { for ultra precision }\end{array}$ & $\begin{array}{l}\text { Cranfield, Precision } \\
\text { Engineering Centre }\end{array}$ & $\begin{array}{l}\text { Cimatron } \\
\text { ForeGone Solutions }\end{array}$ & Cranfield, Dec \\
\hline $\begin{array}{l}\text { Optical Design and } \\
\text { Fabrication }\end{array}$ & $\begin{array}{l}\text { UCL, Optical Sciences } \\
\text { Laboratory }\end{array}$ & $\begin{array}{l}\text { University College London } \\
\text { Zeeko }\end{array}$ & OpTIC, Jan \\
\hline $\begin{array}{l}\text { Surface Engineering and } \\
\text { Coatings }\end{array}$ & $\begin{array}{l}\text { Cranfield, Surface } \\
\text { Engineering Centre }\end{array}$ & PJ Coatings & Cranfield, Feb \\
\hline $\begin{array}{l}\text { Modern Optical } \\
\text { Technologies }\end{array}$ & $\begin{array}{l}\text { Cranfield, Precision } \\
\text { Engineering Centre and } \\
\text { OpTIC }\end{array}$ & $\begin{array}{l}\text { University College London } \\
\text { UK ATC } \\
\text { Imagine Optic } \\
\text { Bookham Technology } \\
\text { Centre for Modern Optics }\end{array}$ & OpTIC, Mar \\
\hline $\begin{array}{l}\text { Laser Micromachining and } \\
\text { Surface Structuring }\end{array}$ & $\begin{array}{l}\text { Cambridge, Centre for } \\
\text { Industrial Photonics, IfM }\end{array}$ & $\begin{array}{l}\text { Oxford Lasers } \\
\text { Laser Micromachining Ltd (LML) } \\
\text { TWI Ltd } \\
\text { Optek Systems }\end{array}$ & Cambridge, Apr \\
\hline
\end{tabular}

Table 1. MSc in Ultra Precision Technologies - taught modules showing industrial partners

Following a course on CADCAM for product design the Taught Element syllabus returns to its optics heartland for the "Optical Design and Fabrication" module, located at the OpTIC technium in North Wales, but taught out of the Optical Design department of University College London. The aim is to provide students with an overview of modern technologies for designing and optimising optical systems, and fabricating precision lenses and mirrors. In line with the rest of the course, practical issues are emphasised, alongside the interactions between the design and fabrication stages of a project. Details include the teaching of ray-tracing and numerical optimisation as design and tolerancing tools for optical systems, and the importance of some theoretical insight to ensure sensible solutions.

The module entitled "Surface Engineering and Coatings" is a good illustration of the marriage between ultra precision engineering and optical engineering which underpins the course as a whole. In addition to providing an understanding of the role that surfaces play in materials behaviour, the module increases focus to concentrate on the optical applications of coating systems. An understanding of the suitable analytical techniques used to evaluate and characterise surfaces and thin samples is also gained. The penultimate module is concerned with the applications of ultra precision technologies to optical and photonic applications. In "Modern Optical Technologies" the student is introduced to market sectors that include optical telecommunications, astronomy, sensors and displays, lasers in nuclear fusion, MOEMS, and holography. Finally, the course relocates to the University of Cambridge for the "Laser Micromachining and Surface Structuring" course from the Centre for Industrial Photonics within the IfM (Institute for Manufacturing). The unique partnership of academic departments that sit at the core of the IKC is apparent from the locations given in Table 1. The MSc is a Cranfield University degree, but the world class expertise of the IKC partners is well represented in the curriculum. 
The taught modules vary in style from traditional lectures for subject based learning (see Figure 3a), to

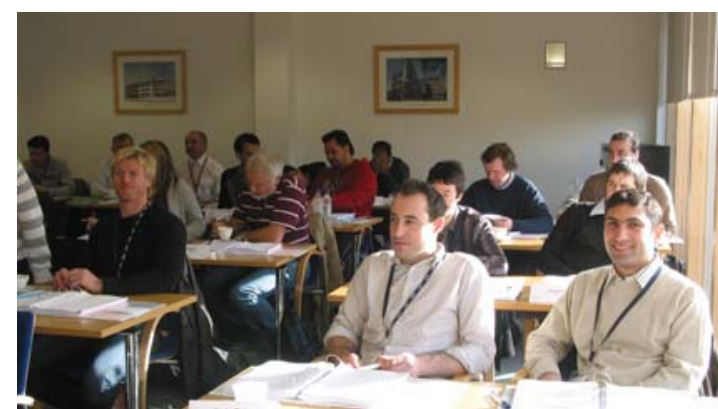

Fig 3a. Taught module in "Optical Test"

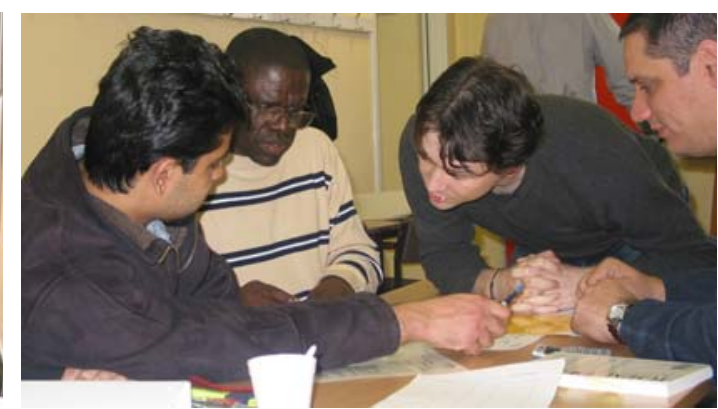

Fig 3b. "Management of Innovation" business simulation

practical sessions with a more problem based learning style. The latter can be found throughout sections of the "Managing innovation and new product development" module (see Figure 3b), whilst experiential learning predominates in the "Computer-aided engineering" module. The different teaching styles are designed to address the need for different learning styles, in an attempt to reduce gender bias ${ }^{4}$ and increase appeal to midcareer change applicants. As discussed by $\mathrm{Rae}^{5}$, entrepreneurial learning can aid the mid-career change applicant by facilitating a successful transition from a role that utilises existing skills and expertise to a new role in a field that utilises newly learned skills and expertise. In making the transition to a career in precision optics or photonics, an experienced candidate may not have the same recollection of basic science and engineering knowledge as a new graduate. This can also be addressed during the Introductory week, and in tutorials held throughout the academic year.

\subsection{The Group Project}

The Group Project provides another dimension to the student learning experience, and an opportunity to align with other qualities required by industry of newly recruited precision engineers. As mentioned earlier, the optics and photonics high technology industries require staff with a high emotional maturity, motivation, and team working skills - in addition to technical knowledge ${ }^{6}$. These are all tested in the Group project phase of the Masters degree. The students, typically in groups of between four and ten in size, undertake a precision engineering project with a study time of 400 notional learning hours. Although the technical output is crucial, and can be sponsored by an industrial partner, the learning from the activity should include a better understanding and experience of working in a project team. The example shown in Figure 4 demonstrates the

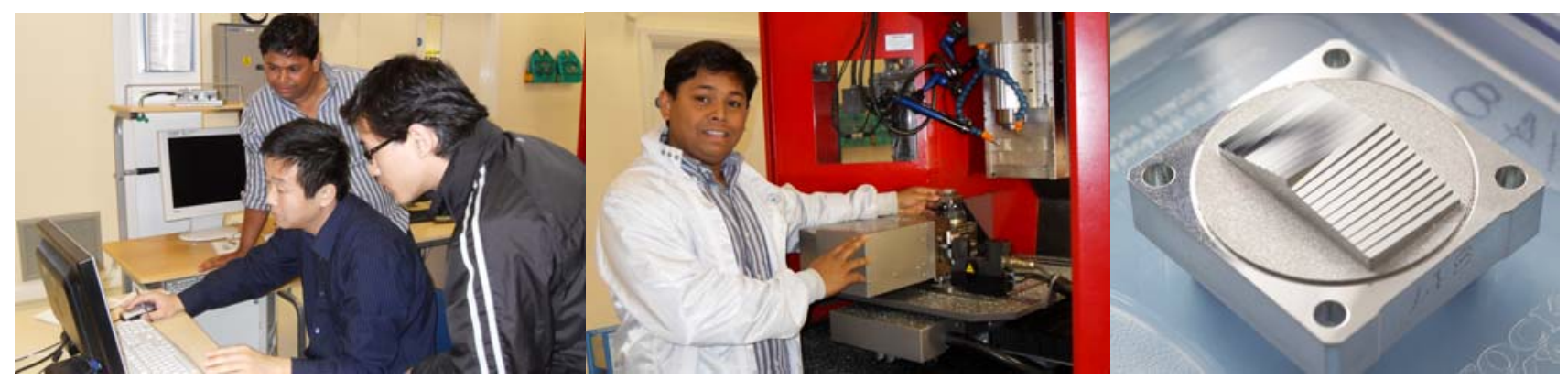

Figure 4. Group Project work: design and machining of complex optical components

challenging nature of a typical project. The 2009 Group Project involved the machining of a image slicer similar to that delivered by Cranfield University to NASA, a component within the MIRI (Mid-InfaRed Instrument) of the James Webb space telescope - scheduled for launch in 2013. 


\subsection{The Individual Project}

The final component of the Masters degree consists of the individual project and its associated thesis. This is intended to be a thorough examination of the student's learning, accounting for $40 \%$ of the overall course mark. It is a feature of the course that great effort is taken to place students in an industrial environment for the duration of their individual projects. From the company perspective the benefits are clear - access to a newly trained precision engineer on a project of interest to the company. For the student too there are considerable benefits, to the extent that the company placement scheme has become an important marketing aid for student recruitment. The student not only gains valuable work experience, but also has the opportunity to practice new skills and enhance their employability ${ }^{7}$. Matching of the individual student to a participating company is a threeway process, once again demonstrating the close relationship between the company, the University, and the student - as drawn schematically in Figure 2. During the early stages of each academic year a "Selection Event" is held at the OpTIC technium, to match students to Companies for the activities of the Individual project (see Figure 5). To date, the event has been enthusiastically attended by both students and companies.

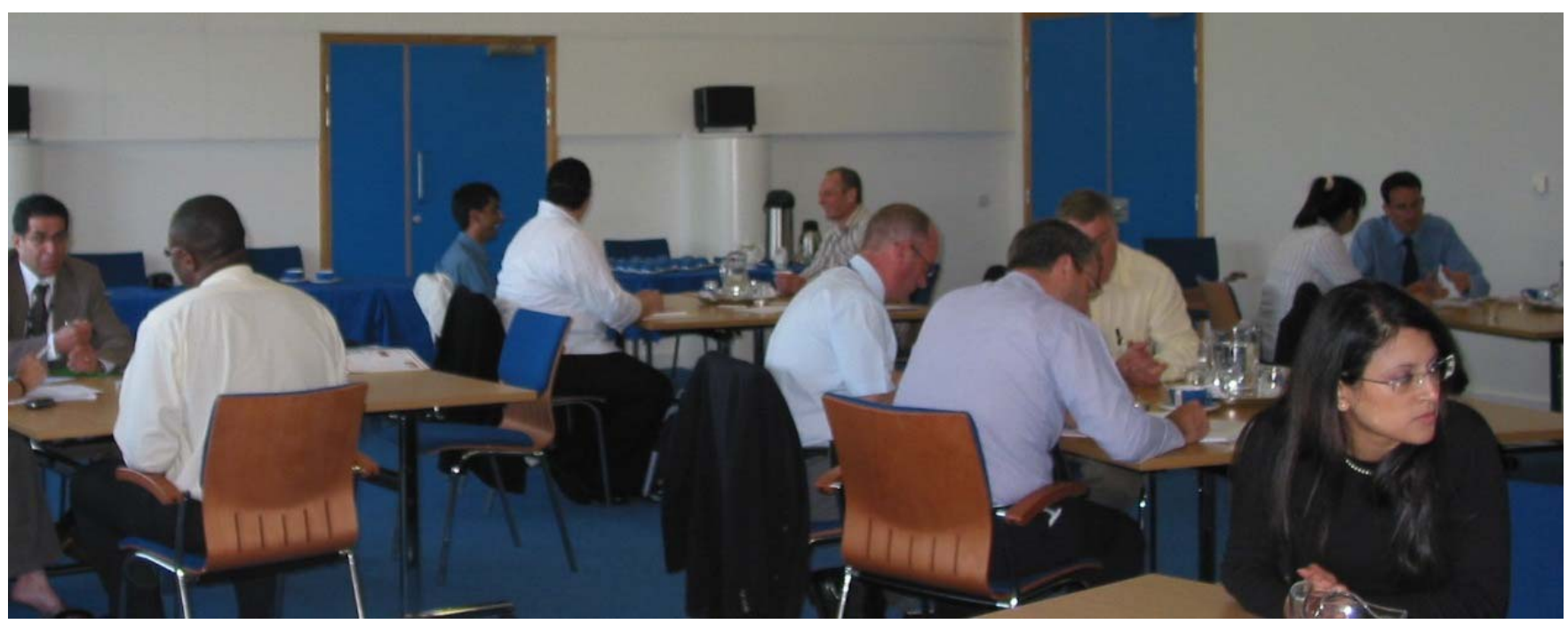

Figure 5 - Company/student matching during "Selection Day" at the OpTIC Technium

During the day, which includes tours and presentations, students are interviewed by the industrialists in order to assess their suitability for project work. Great care is taken to align the wishes of Companies to the expectations of students. In the event that there are more students than participating companies at the Selection event the remaining students are allocated projects within Cranfield University, University College London, or the University of Cambridge.

We should not underestimate the challenge for a new engineer entering the world of industrial manufacturing. Hurdles exist to complicate the transition from Higher Education into the workplace, which has been discussed by many authors ${ }^{8,9,10}$. By undertaking a Masters level project in a company, the student practices their newly acquired technical skills (building on the learning from the taught modules) - but also have to adapt to working within teams and groups which stretch their interpersonal skills and motivations. The Individual project incompany placement programme provides a "safe" and controlled environment within which the student can experiment in order to optimize their effectiveness in a precision engineering role. However the expectations of the course team are more ambitious than this, and the student is challenged to exhibit originality in their research and excellence in their project management and presentation style. This is clearly in evidence from the fact that three students emerged from the first year of the course to progress directly into PhD research projects within the Cranfield University Precision Engineering Centre. 


\subsection{Student recruitment}

As reported previously ${ }^{3}$ we have used a number of approaches to locate, select, and recruit suitable students onto the MSc in "Ultra Precision Technologies". This includes the use of recruitment consultants and specialist web-based engineering databases. However, there is a common thread that links all of our successful recruitment to date, namely the importance of addressing the individual aspirations of applicants. Precision optics and photonics has roles for new graduates and mid-career engineers and scientists ${ }^{11}$. The machining and structuring of surfaces for optical applications can attract a range of academic disciplines. We are also keen to attract students from home and overseas, and to avoid the traditional engineering gender bias ${ }^{12,13}$. These requirements, and the exclusive nature of the course, lead us to treat students as individual clients - an approach that can be continued throughout the period of study owing to Cranfield University's pre-eminent position in terms of staff to student ratio (In the current [2009] Times Higher World University Rankings Cranfield University's achievements included being ranked first in the UK for staff to student ratio, and sixth place in the World).

\section{CPD COURSES AND E-LEARNING PACKAGES}

Each module of the MSc forms a 5-day short course as a stand-alone teaching and learning experience. These mainly attract delegates from the UK and EU plus occasional delegates from further afield. These Continuing Professional Development (CPD) courses provide a means for industrially-based scientists and engineers to update their skills or add to their existing skills. The CPD courses are targeted at different market sectors, with the courses on Modern Optical Technologies, Optical Design and Fabrication, and Laser Micromachining and Surface Structuring being those aimed especially at engineers in the optics and photonics industries and laboratories. As a further aid to knowledge transfer, subsets of some 5-day courses are marketed as 1, 2, or 3 day CPD offerings. Examples of these are the courses in "Ultra Precision Optical Applications" and "Optical Testing". At the more bespoke level, UPS ${ }^{2}$ will design and deliver courses to the optical and photonics industries that are within its portfolio of teaching capabilities.

Aimed primarily at the international market, but also appreciated by UK and EU delegates unable to spare the time to attend the CPD short courses, UPS ${ }^{2}$ is creating distance learning packages that distill the essence of each 5-day CPD short course. The first of these to be released, entitled "Precision Engineering", is a genuine teaching and learning on-line package. In addition to accessing audio recorded lectures and MS Powerpoint slides the delegate is guided through marked assignments, with on-line tutor help available. Screenshots from the first on-line course to be released is shown in Figure 6.

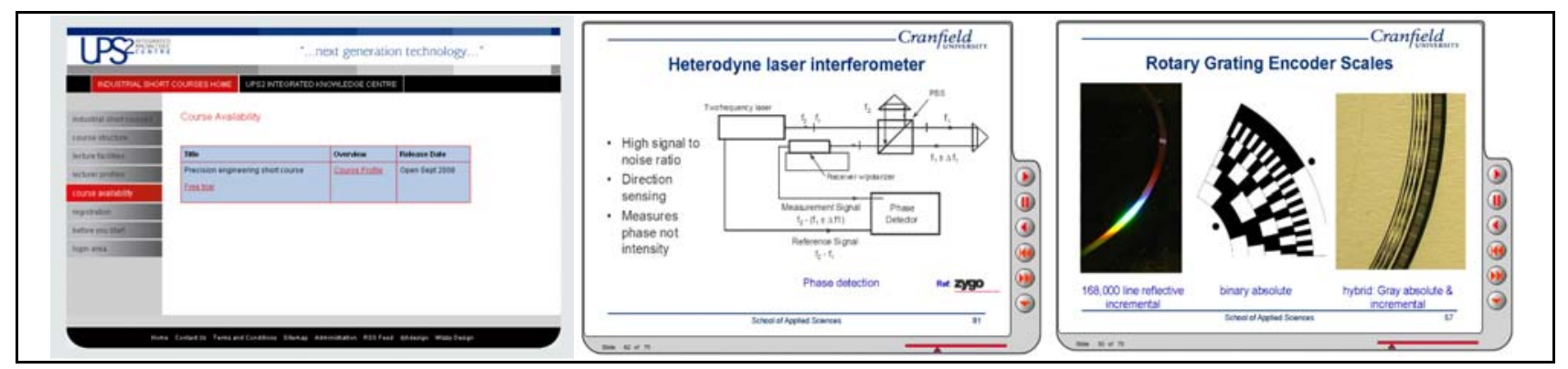

Figure 6 - Actual screenshots from the "Precision Engineering" e-learning package 


\section{MEASURES OF SUCCESS}

The three main measures of success are a blend of academic and industrial. Firstly, as a provider of precision engineering skills to UK industry it follows that the destination of the students at the end of their postgraduate studies is of major interest. Linked to this measure is the output of the company placement scheme, particularly the research carried out by the student and written up in the individual project thesis. All such projects are aimed at understanding, investigating, or solving real engineering problems in an industrial context. Therefore the feedback from participating companies will also be an important yardstick for gauging the success of the venture.

The second measure of success relates to the provision of support to UK and EU manufacturing by the leverage of facilities, equipment, and skills of UPS ${ }^{2}$. This requires a conveyor belt of talent to enter the academic departments of the IKC partner Higher Education institutions, including a desire to study at PhD level. Students emerging with the MSc in Ultra Precision Technologies are in position to fulfil this need. The success of the development and sale of CPD short courses for industrial delegates is also a key success metric. The e-learning and distance learning outputs have a dual role. Apart from generating additional revenue they also provide an advertising platform for the IKC activities and are a means of promoting the UPS ${ }^{2}$ brand.

The third important metric is financial, and reflects the desire that the IKC attains sustainability within the period of Research Council funding. The Masters course resides within a portfolio of knowledge transfer activities, including short courses for industry and the development of novel learning methods such as elearning and distance learning. The special nature of the Masters course does bring additional costs, and these must be covered by outreach events, courses, and teaching packages of the type described above. These items comprise a blended learning approach to knowledge transfer, promoted through both the academic institutions and the UPS ${ }^{2}$ brand.

\section{CURRENT STATUS}

In order to retain competitive advantage, the UK manufacturing engineering industry requires a regular supply of technically excellent and organizationally aware graduates. In the specialist field of precision engineering for optical and photonics applications, where the UK has world class capability, this need is being addressed by a Masters level course in Ultra Precision Technologies with accompanying CPD courses. The portfolio of teaching activities and events has mainly grown out of the needs of the optics industry, and this paper has attempted to show how the industrial links have helped to sculpt a structure for knowledge transfer that incorporates a system to deliver highly skilled postgraduates directly to the workplace.

The MSc in "Ultra Precision Technologies" is in Year 2 of an initial 4-year primary phase. To date 16 "Home" students plus 2 "EU" students plus 4 "Overseas" students, as defined by the UK Higher Education regulations, have entered study. Despite the small sample size the achievement of $73 \%$ "Home" students is extremely encouraging, since the percentage of "Home" students on postgraduate courses (excepting PhD and the Postgraduate Certificate of Education) at all UK HE institutions is $34 \%$. Equally promising is the statistic that $23 \%$ of the total intake are female, which compares favourably with the $8.5 \%$ women who study mechanical engineering at UK Higher Education level. This statistic includes both undergraduate and postgraduate students, but excludes PhD and Postgraduate Certificate of Education students ${ }^{14}$.

The reasons for selecting the course, as given by the students shortly after their first meeting with the participating companies, give an insight into the importance that the industrial partners played in attracting applicants. For the students, company involvement scored highly, in the guise of enhanced employability plus company placements for projects and financial support. It is also encouraging to note that the students have realized that the course is intended to attract people with a range of first degree backgrounds, and that there is scope not only for employment but also higher level research on completion of the Masters degree. Other factors scoring highly demonstrate effective communication during the recruitment process. This reflects well 
on the central Marketing activity within the University, and is also a feature of the intermediate shell process of Figure 2.

Other comments made by the students at the end of the questionnaire mention the ambition to find a more fulfilling role in mechanical engineering or optical applications, or the more general ambition to make a career change. It is also interesting to note the qualifications of applicants, at the time of application. By emphasizing the practical nature of the learning experience, and the opportunity for enhanced employability, students with previous Masters degrees and PhDs have applied. As further evidence for the credibility of the course as a retraining medium the applicants also possessed a first degree in a range of subjects. These included the expected subjects of mechanical engineering and physics, but also students with qualifications in electronics, chemistry, medical devices, materials science, and nuclear engineering.

The companies that have participated in the first two years of the course cover a range of applications, again demonstrating the extensive demand for ultra precision engineers. The companies include Airbus, Gooch \& Housego, PJ Coatings, OpTIC Technium, Qioptiq, PV Crystalox Solar, Perkin Elmer, Microsharp, and Surrey Satellite. Most of these had previous involvement with UPS ${ }^{2}$ and some were sited near to UPS $^{2}$ headquarters at the OpTIC Technium amongst the North Wales opto-electronics business cluster. For this reason it was decided to locate four students in North Wales, to better serve the industrial clients in that region.

Looking forward to the third cohort and beyond, the challenge is to repeat the successes of the first two years as well as expanding the numbers of both students and companies. The IKC is also keen to globalize its operations, including its knowledge transfer activities. The MSc in Ultra Precision Technologies has already attracted interest from Italy and India. The participating companies are expected to grow in number over time, further strengthening the links to the IKC, and taking opportunities to increase the effectiveness of the course to industry. In the future, we can expect the gap between supply and demand for these strategically vital skills to be narrowed.

\section{ACKNOWLEDGEMENTS}

The authors wish to acknowledge the help of their academic colleagues in the development of this work. In particular we would like to recognize the part played in course planning, design and structure by Professor John Corbett and Professor David Allen. Special thanks are also due to the MSc Course Module coordinators and to Cranfield University School of Applied Sciences Marketing team. The industrial contacts are too numerous to list in person, but deserve great credit for their foresight, imagination, and commitment to the programme.

\section{REFERENCES}

[1] Yasin, M., Czuchry, A., Martin, J., Feagins, R. (2000), "An open systems approach to higher learning: the role of joint ventures with business", Industrial Management \& Data Systems, 100/5, pp 227-233.

[2] Kettunen, J. (2006), "Strategies for the cooperation of educational institutions and companies in mechanical engineering", International Journal of Educational Management, Vol. 20 No. 1, pp. 19-28.

[3] Sansom, C.L. and Shore, P. (2008), "Case Study: meeting the demand for skilled precision engineers", Education + Training, Vol. 50 No. 6, pp. 516-529.

[4] Powell, A., Bagilhole, B., Dainty, A. and Neale, R. (2004), "Does the Engineering Culture in UK Higher Education Advance Women's Careers?", Equal Opportunities International, Vol 23 No 7, pp21-38.

[5] Rae, D. (2005), “Mid-career entrepreneurial learning”, Education + Training, Vol. 47 No. 8/9, pp. 652-574. 
[6] Rae, D. (2007), "Connecting enterprise and graduate employability. Challenges to the higher education culture and curriculum?", Education + Training, Vol. 49 No. 8/9, pp. 605-619.

[7] Brown, A.E. (1996), "Communication as the common ground between engineering education and industry", Proceedings of the ASEE 1996 College Industry Education Conference, pp. 101-2.

[8] Heinz, W.R. (1999), From Education to Work, Cambridge University Press, Cambridge, MA

[9] Arnold, J.A. and Mackenzie Davey, K. (1992), "Beyond unmet expectations: a detailed analysis of graduate experiences during the first three years of their career", Personnel Review, Vol. 21 No. 2, pp. 45-68.

[10] Holden,R. and Hamblett,J (2007), "The transition from higher education into work: tales of cohesion and fragmentation", Education + Training, Vol. 49 No. 7, pp. 516-585.

[11] Blackburn, R. and Mackintosh, L (1999), "The entrepreneurship potential of people in the third age: a case of over expectation?" , paper presented at the Small Business and Enterprise Development Conference, University of Leeds, Leeds, March 1999.

[12] Madhill, H. et al (2003), "Making Choices and Making Transitions - Creating A Web Resource", Proceedings of the GASAT 11 International Conference, Mauritius, 6-11th July 2003.

[13] Srivastava, A. (1996), "Widening Access: Women in Construction Higher Education", PhD thesis, Leeds Metropolitan University.

[14] Setwomenstats.org.uk (UK Resource for women in Science, Engineering and Technology) 2004/5, www.setwomenstats.org.uk 